\title{
Fats of Pig and Beef from Benin: Purification, Stability Study, Chemical and Nutritional Composition
}

\author{
Hermann Nounagnon $^{1}$, Bénédicta Kpadonou-Kpoviessi ${ }^{1}$, Berenger Ladele ${ }^{1}$, Pierre Dossou-Yovo ${ }^{2}$, \\ Joachim Gbénou ${ }^{3}$, Salomé Kpoviessi ${ }^{1, ~ *}$ \\ ${ }^{1}$ Department of Chemistry, University of Abomey-Calavi, Cotonou, Benin \\ ${ }^{2}$ Faculty of Sciences and Technics (FAST), University of Abomey-Calavi, Abomey-Calavi, Benin \\ ${ }^{3}$ Faculty of health Sciences (FSS), Faculty of Sciences and Technics (FAST), University of Abomey-Calavi, Cotonou, Benin
}

Email address:

salome.kpoviessi@fast.uac.bj(S.Kpoviessi)

${ }^{*}$ Corresponding author

\section{To cite this article:}

Hermann Nounagnon, Bénédicta Kpadonou-Kpoviessi, Berenger Ladele, Pierre Dossou-Yovo, Joachim Gbénou, Salomé Kpoviessi. Fats of Pig and Beef from Benin: Purification, Stability Study, Chemical and Nutritional Composition. American Journal of Applied Chemistry. Vol. 6, No. 2, 2018, pp. 43-50. doi: 10.11648/j.ajac.20180602.12

Received: February 27, 2018; Accepted: March 13, 2018; Published: April 9, 2018

\begin{abstract}
Animal fats, are used in several western countries in industrial sectors as energy, oleochemistry, animal and human feed but stay under-utilized through Africa. The aim of the present study was to purify and stabilize fats of Bos taurus Linnaeus (BTL) and Sus scrofa domesticus Erxleben (SSDE) from Benin for various uses. Fats from BTL and SSDE were purified using local reagents, for the first time in Benin. The physicochemical properties, nutritional composition and the fatty acid profile were determined, with also, their preserving times. The GC/FID analyzes shown that $100 \mathrm{~g}$ of purified BTL fat contained $65.76 \%$ of saturated fatty acids (SFA), $31.83 \%$ of monounsaturated fatty acids (MUFA) and $2.41 \%$ of polyunsaturated fatty acids (PUFA). In the SSDE fat, $48.57 \%$ of SFA, $38.59 \%$ of MUFA and $12.84 \%$ of PUFA were obtained. The studied fats were rich in unsaturated fatty acids (UFA) such as oleic acid $(34 \%$ and $26 \%$ and for SSDE and BTL respectively) and linoleic acid (11\% and $1 \%$ for SSDE and BTL respectively). Their major saturated acids were palmitic and stearic acids, with respectively $25 \%$ and $35 \%$ for BTL fat and $25 \%$ and $21 \%$ for SSDE fat. The physicochemical parameters such as acid, peroxide, iodine and saponification indexes of the two fats were in agreement with the Codex Stan 211 (1999) recommendations, during all the conservation time. The preserving times of the two purified fats varied according to the temperature of conservation. These purified fats, with interesting physicochemical properties, could be used in agri-food, energy, oleochemistry, cosmetology.
\end{abstract}

Keywords: Purified Fats, Sus scrofa domesticus Erxleben, Bos taurus Linnaeus, Stability, Fatty Acid Profile, Nutritional Properties

\section{Introduction}

Animal fats are substances belonging to the lipid class. They are basically extracted from adipose tissues or milk of animals. Pig (SSDE) and beef (BTL) BTL are animals raised throughout West Africa. In Benin, fish, poultry, pig (SSDE) and beef (BTL) are the most important sources of animal protein. The livestock capital of ruminants accounts for $89.6 \%$ of the total Benin livestock (ruminants, pigs, poultry, rabbits, and aulacodes). Ruminant farming, with a population of 2 to 3 million head, originally practiced mainly in the north of the country (more than 65 percent of the national population), tends to move towards the Center and South [1]. SSDE production is fairly developed and spread throughout the country's rural and urban areas. It is present in all departments of the national territory with a high concentration in those of the South and Central [2].

The local SSDE is the most breed by the producers and its meat, compared to that of the improved breed SSDE, is more 
appreciated by consumers [3]. The improved breeds encountered are the Large White, the Landrace and their mixed breeds often raised in semi-modern to modern conditions. The use of SSDE meat during ceremonies such as weddings, baptisms, birthdays..., the use of SSDE fat in traditional medicine and the frequent gathering of consumers around the many delicatessens located on both sides in the towns and villages of the country justify the high consumption of the meat of pigs [3]. Weighing up to $500 \mathrm{Kg}$ for beef and $150 \mathrm{~kg}$ for pig, the carcass of these animals after slaughter can contain up to $8.5 \%$ of lipid for beef and $12 \%$ for pig [4]. Unfortunately, these lipids, stoked in the adipose tissues, were not valued at their fair value in Benin. Throughout the literature, these fats could be refined from the adipose tissues [5] and their fatty acid profile revealed a high percentage of UFA $(58.8 \%$ and $54.3 \%$ for pig and beef respectively) [4] with oleic acid $(43.5 \%$ and $45.5 \%$ respectively for pig and beef) [6, 7] as major compound. They also contained palmitic and stearic acids (24\% and $13 \%$ respectively for pig, and $22.8 \%$ and $17.1 \%$ respectively for beef) as major SFA [6, 7]. Animal fats, although underutilized in Africa, are used in several industrial sectors (energy, oleochemistry, animal and human feed) in western countries [8]. The aim of this study is to purify and stabilize fats of SSDE and BTL from Benin, using local reagents and in order to valorize them in several promising fields which are still unexplored.

\section{Materials and Method}

\subsection{Chemicals and Reagents}

Orthophosphoric acid $\left(\mathrm{H}_{3} \mathrm{PO}_{4}, 85 \%\right)$ was obtained from Surechem Products LTD Needham Market Suffolk England. The caustic soda in pellets $(\mathrm{NaOH}, 97 \%)$ from Scharlab S. L. Spain. 40 methylester fatty acid components and all reagents (diethyl ether, ethanol 95\%, phenolphthalein, potassium hydroxide, chlorhydric acid, cyclohexane, potassium bromate, potassium iodide, chloroforme, acetic acid, sodium thiosulfate, magnesium sulfate) were obtained from SigmaAldrich (Steinhein, Germany) and absolute ethanol obtained from the labotec laboratory (Brussels, Belgium). All chemical products and reagents were of high quality and analytic grade.

\subsection{Animal Material}

The adipose tissues of BTL and SSDE were purchased in the Cotonou slaughterhouses and kept in a cooler whose temperature has been maintained between 0 and $4 \pm 1^{\circ} \mathrm{C}$. The samples were taken to the laboratory and store in the freezer at $4 \pm 1{ }^{\circ} \mathrm{C}$.

\subsection{Fats Purification}

The adipose tissues of BTL and SSDE were refined using the chemical process. Small pieces of adipose tissues were heated at about 60 to $70^{\circ} \mathrm{C}$. Then the melted fat was separated from meat residues by filtration and purified following the different steps:

- Degumming: removal of the mucilage by addition of phosphoric acid to the obtained oil heated at about $90{ }^{\circ} \mathrm{C}$. Proteins and carbohydrates were separated from the oil by filtration.

- Neutralization: elimination of short carbon chains fatty acids and free acids that affect taste and accelerate denaturation of fat, by addition of $15 \%$ of sodium hydroxide solution $(\mathrm{NaOH})$. The neutralized acids were separated from the oil by washing with water. - Discoloration: at about $90{ }^{\circ} \mathrm{C}$, a mixture of kaolin and coal was added. Dyes, pigments and heavy metals as well as various impurities or undesirable compounds were complexed and separated. Deodorization: then we heated the obtained fat at high temperature (about $240{ }^{\circ} \mathrm{C}$ ). This last step allowed us to evacuate unpleasant odors and taste. Volatile compounds and pesticides were also eliminated. All these different steps allowed us to obtained pure fats.

\subsection{Fat Analysis Methods}

\subsubsection{Physicochemical Properties Determination}

The values of the smoke and melting points, acid (AI), saponification $(\mathrm{SI})$, iodine $\left(\mathrm{I}_{\mathrm{I}}\right)$ and peroxide $(\mathrm{PVs})$ values were determined on the refined fat using standard methods (BS684-1.8, NFT60-204, NFT 60-206, NF ISO 3961 and NFT 60-220 respectively).

\subsubsection{Unsaponifiable Matter Extraction}

The content and isolation of the unsaponifiable matter were obtained by the method described by kpoviessi et al. [9] including saponification of oil in $\mathrm{KOH} /$ ethanol $(2 \mathrm{~N})$ at reflux for $2 \mathrm{~h}$, extraction of unsaponifiable matter with hexane, washing of the organic phase with $\mathrm{NaOH} / \mathrm{H}_{2} \mathrm{O}(3 \%)$, removing of traces of water, filtration, drying and determination of weight on a Mettler Toledo Balance.

\subsubsection{GC-FID Determination of Fatty Acid Profile}

Fatty acid profiles were obtained by gas-liquid chromatography of the fatty acid methyl ester derivatives. Fatty acids from the refined fats were methylated in a solution of $\mathrm{KOH}$ in methanol $(0.1 \mathrm{~mol} / \mathrm{L})$ at $70^{\circ} \mathrm{C}$ for 60 min, then in a solution of $\mathrm{HCl}$ in methanol $(1.2 \mathrm{~mol} / \mathrm{L})$ at $70^{\circ} \mathrm{C}$ for $20 \mathrm{~min}$, and finally extracted with hexane. Fatty acid methyl esters (FAMEs) were separated and quantified with a gas-liquid chromatograph (GC Trace ThermoQuest, Milan, Italy) equipped with a flame ionization detector, an automatic injector and a fused silica capillary column ( $100 \mathrm{~m} \times 0.25 \mathrm{~mm}$ internal diameter) coated with a $0.2 \mathrm{~mm}$ film of biscyanopropyl-polysiloxane (Rt-2560, Restek, Bellefonte, PA, USA). The system used $\mathrm{H}_{2}$ as the carrier gas and operated at a constant pressure of $200 \mathrm{kPa}$. Splitless injection mode was used minimizing the risk of discrimination between FAs with very different volatilities. The initial oven temperature was $80^{\circ} \mathrm{C}$; it increased at $25^{\circ} \mathrm{C} / \mathrm{min}$ to $175^{\circ} \mathrm{C}$ (held for $25 \mathrm{~min}$ ), then increased at $10^{\circ} \mathrm{C} / \mathrm{min}$ to $205^{\circ} \mathrm{C}$ (held for $4 \mathrm{~min}$ ), then increased at $10^{\circ} \mathrm{C} / \mathrm{min}$ to $225^{\circ} \mathrm{C}$ (held for $20 \mathrm{~min}$ ) and 
finally decreased at $20^{\circ} \mathrm{C} / \mathrm{min}$ to $80^{\circ} \mathrm{C}$. The temperature of the flame ionization detector was maintained at $255^{\circ} \mathrm{C}$. Hydrogen flow to the detector was $35 \mathrm{~mL} / \mathrm{min}$ and air flow was $350 \mathrm{~mL} / \mathrm{min}$. A calibration mixture of fatty acid standards was processed in parallel. The data were analyzed by using the Chromquest 3.0 software. Each peak was identified and quantified by comparison of retention times with pure FAME standards. Fatty acids are expressed as the percent of total fatty acids quantified within an individual sample. A total of forty pure FAME standards were used.

\section{Results and Discussion}

\subsection{Obtaining of Refined Fats}

The refined fats were obtained from the adipose tissues after application in order, of different process: degumming, neutralization, discoloration and deodorization. The kaolin and the coal used in the discoloration process were local products. These operations allowed to obtain, for BTL, a solid refined fat at room temperature $\left(27 \pm 1^{\circ} \mathrm{C}\right)$, whitish in color, neutral in taste and odorless. The fat of SSDE was pasty at room temperature; white-gray, neutral and odorless (Table 1).

Table 1. Physicochemicals characteristics of BTL and SSDE fats (mean $\pm s d, n=3$ ).

\begin{tabular}{|c|c|c|c|c|}
\hline \multirow{2}{*}{ Parameters } & \multicolumn{2}{|l|}{ BTL fat } & \multicolumn{2}{|l|}{ SSDE fat } \\
\hline & Sample & Standard & Sample & Standard \\
\hline Melting point $\left({ }^{\circ} \mathrm{C}\right)$ & 54 & $45-50^{\mathrm{a}}$ & 43 & $26-40^{\mathrm{a}}$ \\
\hline Smoke point $\left({ }^{\circ} \mathrm{C}\right)$ & 207 & $210^{\mathrm{c}}$ & 216 & $210^{\mathrm{c}}$ \\
\hline Aspect & $\begin{array}{l}\text { Solid at } \\
27 \pm 1^{\circ} \mathrm{C}\end{array}$ & $\begin{array}{l}\text { Solid ou semi- } \\
\text { solid at } 20^{\circ} \mathrm{C}^{\mathrm{a}}\end{array}$ & $\begin{array}{l}\text { Paste at } \\
27 \pm 1{ }^{\circ} \mathrm{C}\end{array}$ & $\begin{array}{l}\text { Solid ou semi- } \\
\text { solid at } 20^{\circ} \mathrm{C}^{\mathrm{a}}\end{array}$ \\
\hline Color & Whitish & White-gray to yellow ${ }^{a}$ & White-gray & Gray to yellow ${ }^{\mathrm{a}}$ \\
\hline Taste & Neutral & Neutral $^{\mathrm{a}}$ & Neutral & Neutral $^{\mathrm{a}}$ \\
\hline Acid value (mg KOH / g) & $1.01 \pm 0.10$ & $0.6^{\mathrm{a}}$ & $0.94 \pm 0.08$ & $1.3^{\mathrm{a}}$ \\
\hline Peroxide value (meq $\mathrm{O}_{2} / \mathrm{Kg}$ ) & $0.23 \pm 0.04$ & $\leq 15.0^{\mathrm{a}}$ & $5.26 \pm 0.02$ & $\leq 14.0^{\mathrm{a}}$ \\
\hline Iodine value $\left(\mathrm{g} \mathrm{I}_{2} / 100 \mathrm{~g}\right)$ & $35 \pm 0.01$ & $40^{\mathrm{b}}$ & $57 \pm 0.21$ & $46.0-66.0^{\mathrm{b}}$ \\
\hline Saponification value (mg de $\mathrm{KOH} / \mathrm{g}$ ) & $201 \pm 5.80$ & $197^{\mathrm{b}}$ & $191.5 \pm 6.75$ & $193.0-200.0^{\mathrm{b}}$ \\
\hline Unsaponifiable (\%) & $0.04 \pm 0.00$ & $\leq 1.2^{\mathrm{b}}$ & $0.29 \pm 0.03$ & $\leq 1^{\mathrm{b}}$ \\
\hline
\end{tabular}

BTL: Bos taurus Linnaeus; SSDE: Sus scrofa domesticus Erxleben

${ }^{a}$ CODEX STAN 211, 1999 - Amended in 2009, 2013 and 2015 [16].

${ }^{\mathrm{b}}$ ALINORM 99/17 [10].

${ }^{\mathrm{c}}$ Nutrition Infos, Intimate toxins. 2013 [17].

\subsection{Physicochemical Characteristics of Fats}

The physicochemical characteristics including acid, saponification, iodine, peroxide values of the studied fats are listed in Table 1.

The acid value of BTL and SSDE fats, respectively 1.01 and $0.94 \mathrm{mg} \mathrm{KOH} \mathrm{/} \mathrm{g}$ of fat, were in accordance with the standard value $(2.5 \mathrm{mg} \mathrm{KOH} \mathrm{/} \mathrm{g)} \mathrm{of} \mathrm{ALINORM} \mathrm{[10].} \mathrm{The}$ refined fats could be used in food industry.

The saponification value of BTL fat $(201 \mathrm{mg} \mathrm{KOH} / \mathrm{g})$ was in accordance with standard value $(190-202 \mathrm{mg} \mathrm{KOH} /$ g) [10]. While that of SSDE (191.5 mg KOH / g) was closed to standard values $(192.0-203.0 \mathrm{mg} \mathrm{KOH} / \mathrm{g})$. These two values were also closed to those of Palm oil $(190-209 \mathrm{mg}$ $\mathrm{KOH} / \mathrm{g}$ ) and could orient these fats in soap manufacturing.

The BTL fat iodine value, $35 \mathrm{~g}$ of $\mathrm{I}_{2} / 100 \mathrm{~g}$ was lower than reported value $40-53 \mathrm{~g}$ of $\mathrm{I}_{2} / 100 \mathrm{~g}$ of the standard [10].
However, that of $57 \mathrm{~g}$ of $\mathrm{I}_{2} / 100 \mathrm{~g}$ of SSDE was within the range $55-65 \mathrm{~g}$ of $\mathrm{I}_{2} / 100 \mathrm{~g}$. With these values, BTL fat seemed to be less unsaturated than SSDE one.

For both fats, peroxide values $\left(0.23\right.$ and 5.26 meq $\mathrm{O}_{2} / \mathrm{Kg}$ respectively for BTL and for SSDE) were much lower than the maximum value $\left(10.0\right.$ meq $\left.\mathrm{O}_{2} / \mathrm{Kg}\right)$ prescribed for food fat [10], showing the very good quality of the studied fats.

The unsaponifiable value of BTL and SSDE $(0.04 \pm 0.00$ and $0.29 \pm 0.05$ respectively) were in accordance with standards values ( $\leq 1$ for SSDE and $\leq 1.2$ for BTL) [10].

\subsection{Fatty Acids Profile of SSDE and BTL Fats}

Analysis of the fatty acid profile showed the presence of 19 and 23 fatty acids for SSDE and BTL respectively (Table 2).

Table 2. Fatty acids composition of SSDE and BTL fats expressed in $\mathrm{g} / 100 \mathrm{~g}$ of purified fats. (mean $\pm s d, n=3$ ).

\begin{tabular}{lll}
\hline \multirow{2}{*}{ Fatty acids } & g TFA & \\
\cline { 2 - 3 } & SSDE & BTL \\
\hline Caproic acid (C6:0) & $0.10 \pm 0.01$ & $0.10 \pm 0.03$ \\
Capric acid (C10:0) & - & $0.10 \pm 0.02$ \\
Lauric acid (C12:0) & $0.21 \pm 0.01$ & $0.12 \pm 0.01$ \\
Myristic acid (C14:0) & $1.45 \pm 0.00$ & $3.03 \pm 0.14$ \\
Myristoleic acid (C14:1, c9) & - & $0.13 \pm 0.01$ \\
Pentadecylic acid (C15:0) & - & $0.50 \pm 0.01$ \\
\hline
\end{tabular}




\begin{tabular}{|c|c|c|c|}
\hline \multirow{2}{*}{ Fatty acids } & \multicolumn{2}{|l|}{ g TFA } & \multirow{2}{*}{ RDI } \\
\hline & SSDE & BTL & \\
\hline Palmitic acid (C16:0) & $24.59 \pm 0.01$ & $24.50 \pm 0.18$ & \\
\hline trans Palmitoleic acid $(\mathrm{C} 16: 1, \mathrm{t} 9)$ & _- & $0.61 \pm 0.00$ & \\
\hline Palmitoleic acid $(\mathrm{C} 16: 1, \mathrm{c} 9)$ & $1.11 \pm 0.00$ & $1.06 \pm 0.03$ & \\
\hline Margaric acid (C17:0) & $0.45 \pm 0.00$ & $1.93 \pm 0.01$ & \\
\hline Stearic acid $(\mathrm{C} 18: 0)$ & $21.36 \pm 0.05$ & $34.99 \pm 0.53$ & \\
\hline Elaidic acid $(\mathrm{C} 18: 1, \mathrm{t} 9)$ & $0.10 \pm 0.00$ & $0.38 \pm 0.07$ & \\
\hline Trans Vaccenic acid $(\mathrm{C} 18: 1, \mathrm{t} 11)$ & $0.61 \pm 0.01$ & $2.97 \pm 0.02$ & \\
\hline Oleic acid (C18:1, c9) & $34.37 \pm 0.00$ & $25.94 \pm 0.04$ & \\
\hline Vaccenic acid $(\mathrm{C} 18: 1, \mathrm{c} 11)$ & $1.47 \pm 0.00$ & $0.61 \pm 0.00$ & \\
\hline Linoleic acid (C18:2, c9c12) & $10.54 \pm 0.02$ & $0.97 \pm 0.02$ & $11-17 \mathrm{~g} /$ day \\
\hline Arachidic acid (C20:0) & $0.41 \pm 0.00$ & $0.39 \pm 0.01$ & \\
\hline Gadoleic acid (C20:1, c11) & $0.93 \pm 0.00$ & $0.13 \pm 0.00$ & \\
\hline Linolenic acid (C18:3, c9c12c15) & $0.50 \pm 0.00$ & $0.38 \pm 0.01$ & $1.1-1.6 \mathrm{~g} /$ day \\
\hline Eicosadien acid (C20:2, c11c14) & $0.40 \pm 0.01$ & _ & \\
\hline Arachidonic acid (C20:4, c5c8c11c14) & $0.34 \pm 0.00$ & - & \\
\hline Rumenic acid (C18:2conj, c9t11) & _- & $0.19 \pm 0.00$ & \\
\hline Octadecatetraenoïc acid (C18:4, c6c9c12c15) & - & $0.19 \pm 0.04$ & \\
\hline Behenic acid (C22:0) & & $0.10 \pm 0.00$ & \\
\hline Docosapentaenoic acid (C22:5, c7c10c13c16c19) & $0.34 \pm 0.00$ & _- & \\
\hline Docosahexaenoic acid: DHA (C22:6, c4c7c10c13c16c19) & $0.72 \pm 0.08$ & $0.68 \pm 0.14$ & $0.5 \mathrm{~g} /$ day \\
\hline$\omega 6 / \omega 3$ & 7.23 & 0.78 & \\
\hline Total trans fatty acid & 0.71 & 3.54 & \\
\hline Total cis acid & 50.10 & 30.04 & \\
\hline MUFA / PUFA & 3.01 & 13.21 & \\
\hline SFA / UFA & 0.94 & 1.92 & \\
\hline
\end{tabular}

SSDE: Sus scrofa domesticus Erxleben; BTL: Bos taurus Linnaeus; RDI: recommended daily intake; TFA: total fatty acids; MUFA: mono unsaturated fatty acid; PUFA: poly unsaturated fatty acid; SFA: saturated fatty acid; UFA: unsaturated fatty acid

The unsaturated fatty acids (UFA) of BTL fat account for $34.24 \%$ of total fatty acids and this value was almost half that of SFA $(65.76 \%)$. With the high percentage of SFA, BTL fat was solid at room temperature $\left(27 \pm 1^{\circ} \mathrm{C}\right)$, relatively stable, can be heated at high temperature and kept for longer [11]. Oleic (25.94\%), stearic (34.99\%) and palmitic (24.50\%) fatty acids were the major components (Table 2). The ratio SFA and UFA of BTL fat (1.92) was higher than recommended value (1) of dieticians [12].

Among MUFA, palmitoleic acid percentage (1.06) was higher than those generally obtained in vegetal oil and fat $(<$ $1 \%$ ) [13]. Palmitoleic and oleic acids content were inferior compared to reported values $(2.5 \%$ and $45.5 \%$ respectively), and stearic acid value was twice (17.1\%) [7].

The presence of vaccenic acid $(0.61 \%)$, elaidic acid $(0.38 \%)$, trans vaccenic acid $(2.97 \%)$ and the high percentage of trans fatty acids proved that the studied fat was from animal. The total value of trans fatty acids $(3.54 \%)$ was close to that $(5-10 \%)$ reported by Sonntag [13]. The ratio MUFA and PUFA (13.21 was very high and showed that this fat contained more MUFA and would be suitable for frying. The ratio $\omega 6 / \omega 3$ of 0.78 was lower than the recommended value of 4 [14]. The percentage of $\omega 3$ acid in BTL fat was higher than 1 and was an advantage for this fat.

Concerning SSDE fat, UFA account for $51.43 \%$ of total fatty acids and this value was slightly higher than that of SFA (48.57\%). The high percentage of UFA can explain in part the pasty and solid appearance of this fat at room temperature $\left(27 \pm 1^{\circ} \mathrm{C}\right)$ and at $4 \pm 1^{\circ} \mathrm{C}$ respectively. The probability of an oxidative polymerization (of SSDE fat) was high when highly heated during frying [15]. Oleic (34.37\%), stearic $(21.36 \%)$ and palmitic $(24.59 \%)$ acids were the major components (Table 2). Linoleic acid percentage (10.54) in this fat was closed to that obtained by Iverson (11.2\%) [6]; but the oleic acid percentage was less (43.5) and that of stearic acid was higher (13.0\%) [6]. These differences could be explained by the variation in the animal feeds composition and in the animal races [4]. The ratio SFA and UFA in SSDE fat (0.94) was lower than the recommended value (1) of dieticians [12]. Among MUFA, palmitoleic acid percentage (1.11) was higher than those generally obtained in vegetal oil and fat $(<1 \%)$ [13]. The $\omega 6 / \omega 3$ ratio of 7.23 was higher than the recommended value (4) [14]. However, the percentage of $\omega 3$ (1.56) in this fat was very interesting. The trans-unsaturated fatty acids percentage (TUFA) was $0.71 \%$ and was lower than that of BTL. It confirms that the studied SSDE fat was also from animal origin.

The values of the total fatty acids (SFA, MUFA, PUFA), Linoleic and Linolenic acids were compared to those of the reference (CE Rules and the CODEX STAN 211) and other studies for BTL (Table 3) and for SSDE (Table 4) and showed some difference between values. These differences could be explained be the influence of the animals origin and consequently of animals nutrition on their fatty acids profiles. 
Table 3. Comparative values of total fatty acids in BTL fat with those of the reference (mean $\pm s d, n=3$ ).

\begin{tabular}{llllll}
\hline & Purified fats & CE Rules $^{\text {a }}$ & Standard & & Other studies \\
\hline$\sum$ SFA & $65.76 \pm 0.94$ & 54.00 & $<54.00$ & $>44.5^{\mathrm{c}}$ & $44.1^{\mathrm{d}}$ \\
$\sum$ MUFA & $31.83 \pm 0.17$ & 42.00 & $<43.00$ & $>48.50^{\mathrm{c}}$ & $48.7^{\mathrm{d}}$ \\
$\sum$ PUFA & $2.41 \pm 0.21$ & 3.00 & $<4.50$ & $>3.43^{\mathrm{c}}$ & $7.4^{\mathrm{d}}$ \\
Linoleic acid & $0.97 \pm 0.02$ & 2.00 & 3.00 & $3.23^{\mathrm{c}}$ & $7.2^{\mathrm{d}}$ \\
Linolenic acid & $0.38 \pm 0.01$ & 0.80 & $<1.50$ & $0.10^{\mathrm{c}}$ & $0.2^{\mathrm{d}}$ \\
\hline
\end{tabular}

SFA: saturated fatty acid; MUFA: mono unsaturated fatty acid; PUFA: poly unsaturated fatty acid

${ }^{\text {a }}$ Regulation (EC) No 608/2004 [19].

${ }^{\mathrm{b}}$ CODEX STAN 211, 1999 - Amended in 2009, 2013 and 2015 [16].

${ }^{c}$ MRAD et al., 2009 [18].

${ }^{\mathrm{d}}$ Sreenivasan et al., 1968 [7].

Table 4. Comparative value of total fatty acids in SSDE fat with those of the reference. (mean $\pm s d, n=3$ ).

\begin{tabular}{lllll}
\hline & Purified fats & CE Rules $^{\text {a }}$ & Standard $^{\text {b }}$ & Other study $^{\text {c }}$ \\
\hline$\sum$ SFA & $48.57 \pm 0.08$ & 44.00 & $<44.26$ & $<49.50$ \\
$\sum$ MUFA & $38.59 \pm 0.01$ & 46.00 & $<11.50$ & 46.71 \\
$\sum$ PUFA & $12.84 \pm 0.12$ & 11.00 & 8.00 & 13.21 \\
Linoleic acid & $10.54 \pm 0.02$ & 10.50 & $<1.50$ & 11.2 \\
Linolenic acid & $0.50 \pm 0.01$ & 0.85 & 1.3 \\
\hline
\end{tabular}

SFA: saturated fatty acid; MUFA: mono unsaturated fatty acid; PUFA: poly unsaturated fatty acid

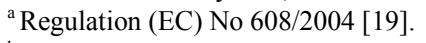

${ }^{\mathrm{b}}$ CODEX STAN 211, 1999 - Amended in 2009, 2013 and 2015 [16].

c Iverson et al., 1965 [6].

\subsection{Fat Stability at $4 \pm 1^{\circ} \mathrm{C}$ and at Room Temperature $27 \pm 1^{\circ} \mathrm{C}$}

\subsubsection{BTL Fat Stability}

To determine the BTL fat duration of conservation, the samples were exposed separately to room temperature $\left(27 \pm 1^{\circ} \mathrm{C}\right)$ and to freezer temperature $\left(4 \pm 1^{\circ} \mathrm{C}\right)$ for a period of 180 days.

The values of quality indices (acid and peroxide) determined during the storage period were shown in Figures 1 and 2.

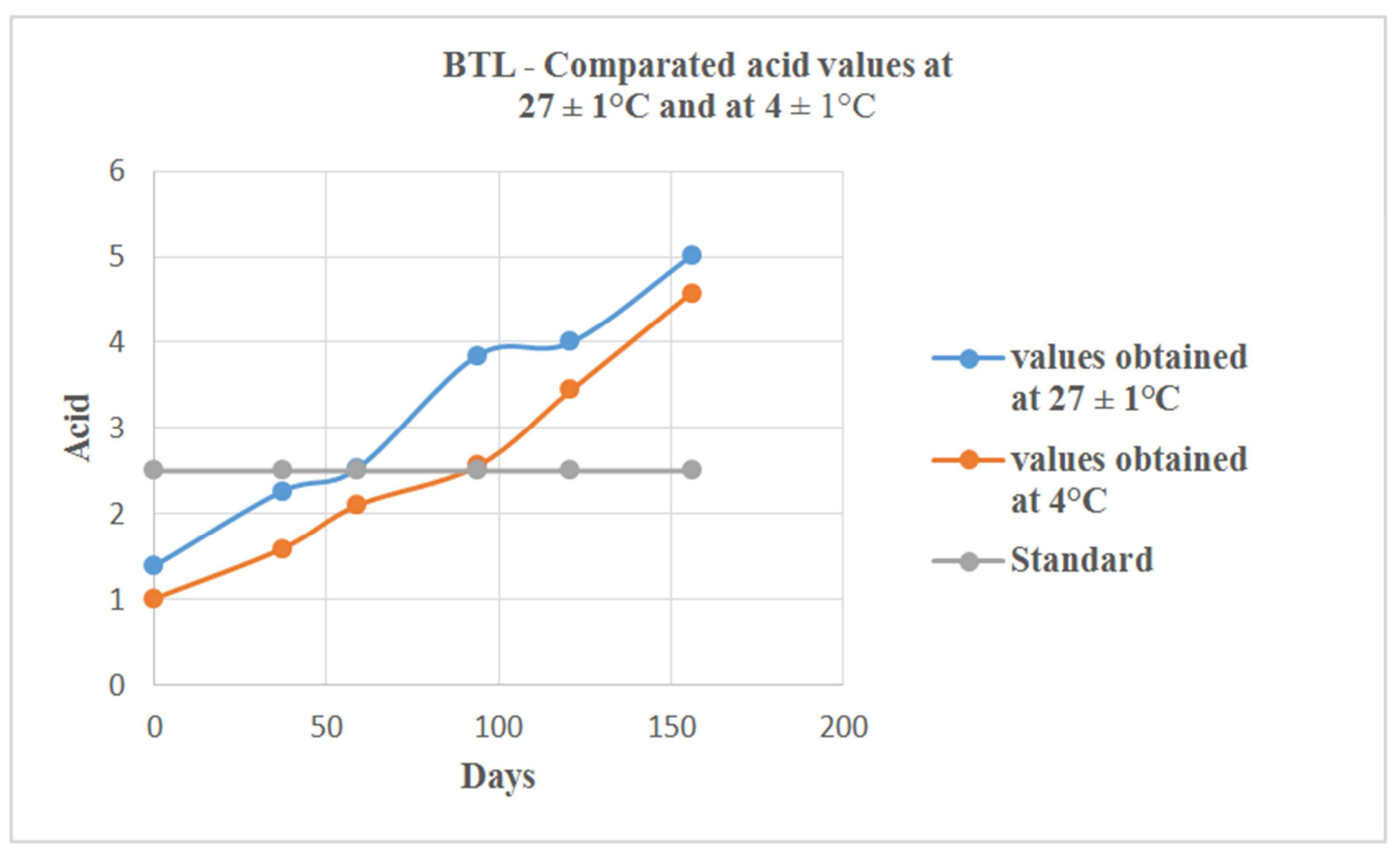

Figure 1. BTL, acid evolution at room temperature $27 \pm 1^{\circ} \mathrm{C}$ and at $4 \pm 1^{\circ} \mathrm{C}$. 


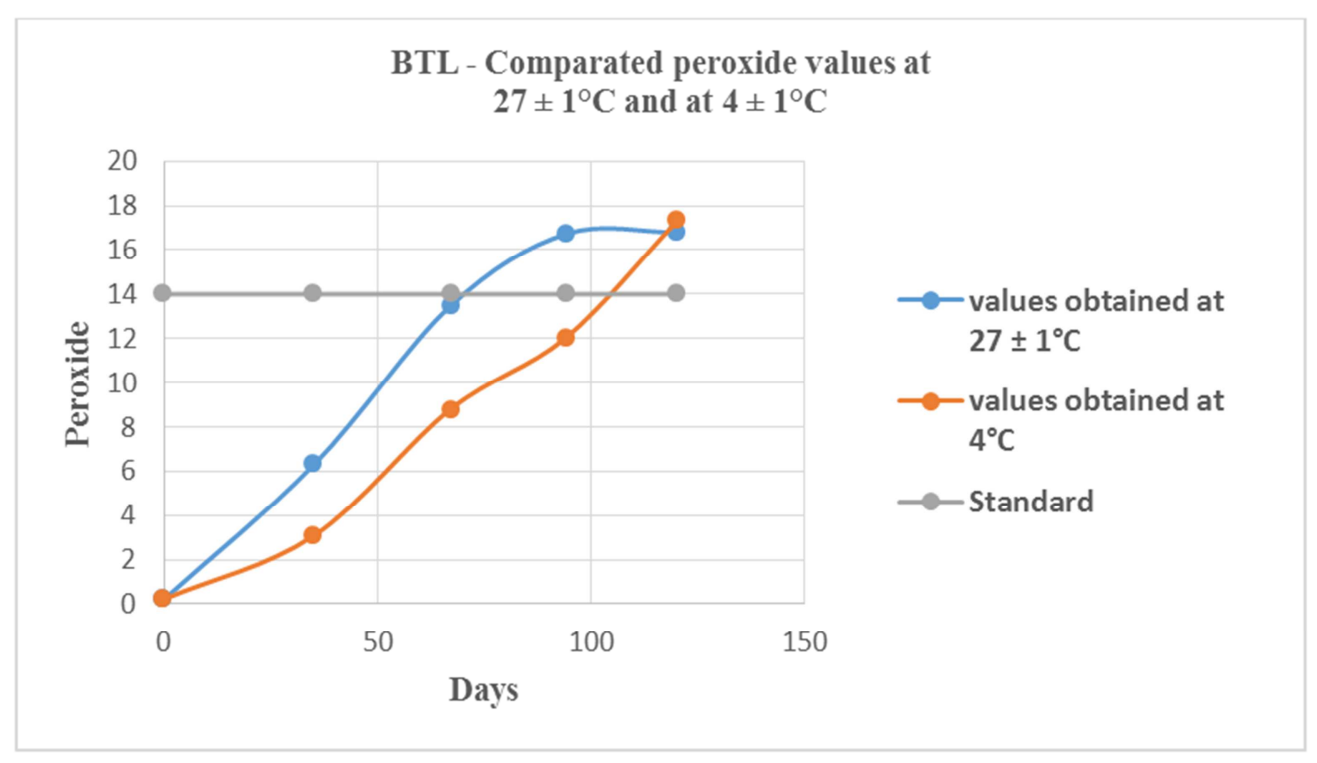

Figure 2. BTL, evolution of the peroxide values at room temperature $27 \pm 1{ }^{\circ} \mathrm{C}$ and at $4 \pm 1{ }^{\circ} \mathrm{C}$.

When the refined fat of BTL was stored at $27 \pm 1^{\circ} \mathrm{C}$, the standard maximum value set at $2.5 \mathrm{mg} \mathrm{KOH} / \mathrm{g}$ was reached after 59 days but when the fat was kept under $4 \pm 1^{\circ} \mathrm{C}$, the maximum value was reach after 94 days. At the same time, the peroxide values were determined. The maximum value of 14.0 meq $\mathrm{O}_{2} / \mathrm{Kg}$ was reached after 68 days of storage at 27 $\pm 1^{\circ} \mathrm{C}$ and after 110 days if the fat was kept at $4 \pm 1{ }^{\circ} \mathrm{C}$. From the analysis of these data, it appears that the peroxide value increased at the same time as the acidity one, whatever the temperature at which the fat was conserved. These values were summarized in Table 5 and showed that this fat could be conserved at freezer temperature $\left(4^{\circ} \mathrm{C}\right)$ during 94 days with preservation of quality properties and at room temperature during 59 days.

Table 5. Maximum time (day) of storage of BTL and SSDE fats at $4 \pm 1^{\circ} \mathrm{C}$ and at $27 \pm 1^{\circ} \mathrm{C}$ (mean $\pm s d, n=3$ ).

\begin{tabular}{|c|c|c|c|c|}
\hline \multirow{2}{*}{ Sample Parameter } & \multicolumn{2}{|l|}{ BTL } & \multicolumn{2}{|l|}{ SSDE } \\
\hline & $4 \pm 1^{\circ} \mathrm{C}$ & $27 \pm 1^{\circ} \mathrm{C}$ & $4 \pm 1^{\circ} \mathrm{C}$ & $27 \pm 1^{\circ} \mathrm{C}$ \\
\hline Acid value & 94 day & 59 day & 54day & 43 day \\
\hline Peroxide value & 110 day & 68 day & 95day & 67 day \\
\hline
\end{tabular}

BTL: Bos taurus Linnaeus, SSDE: Sus scrofa domesticus Erxleben

\subsubsection{SSDE Fat Stability}

The quality values (acid and peroxide) of SSDE fat conserved at room temperature $\left(27 \pm 1{ }^{\circ} \mathrm{C}\right)$ and at freezer temperature $(4$ $\pm 1^{\circ} \mathrm{C}$ ) for 180 days were determined (Figures 3 and 4 ).

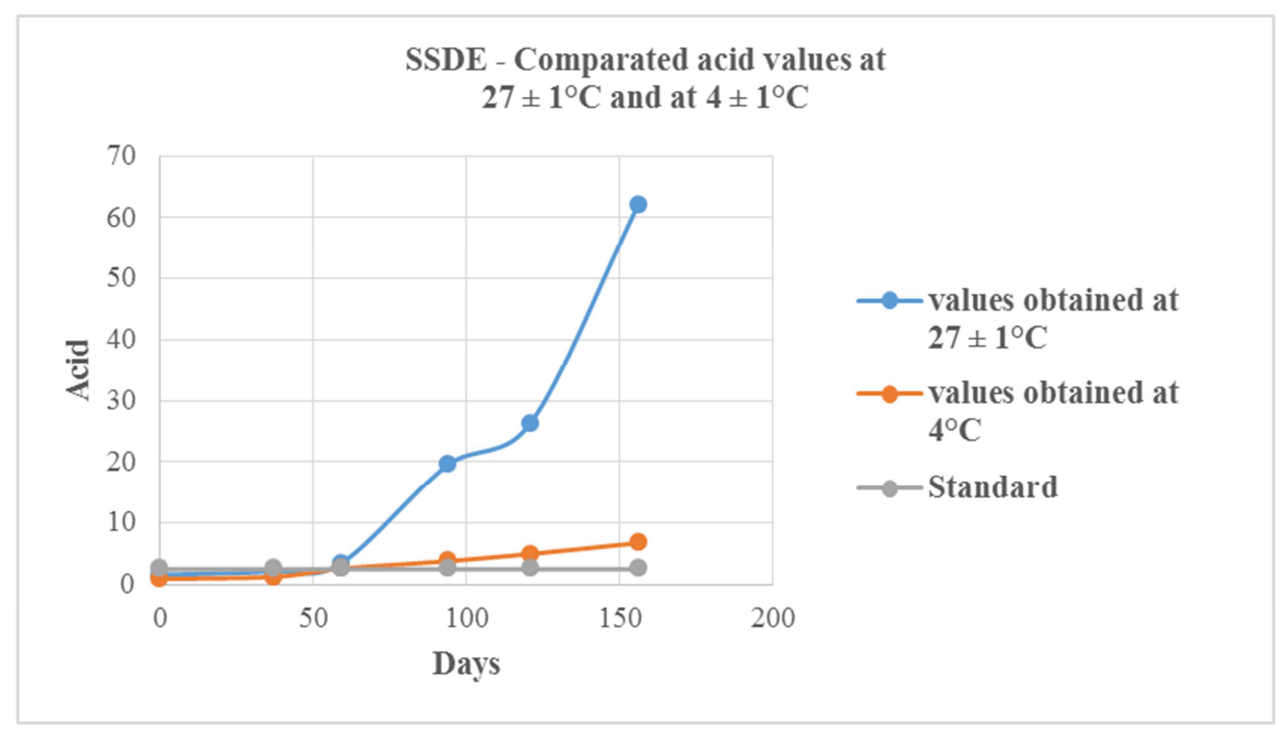

Figure 3. SSDE, acid evolution at room temperature $27 \pm 1^{\circ} \mathrm{C}$ and at $4 \pm 1{ }^{\circ} \mathrm{C}$. 


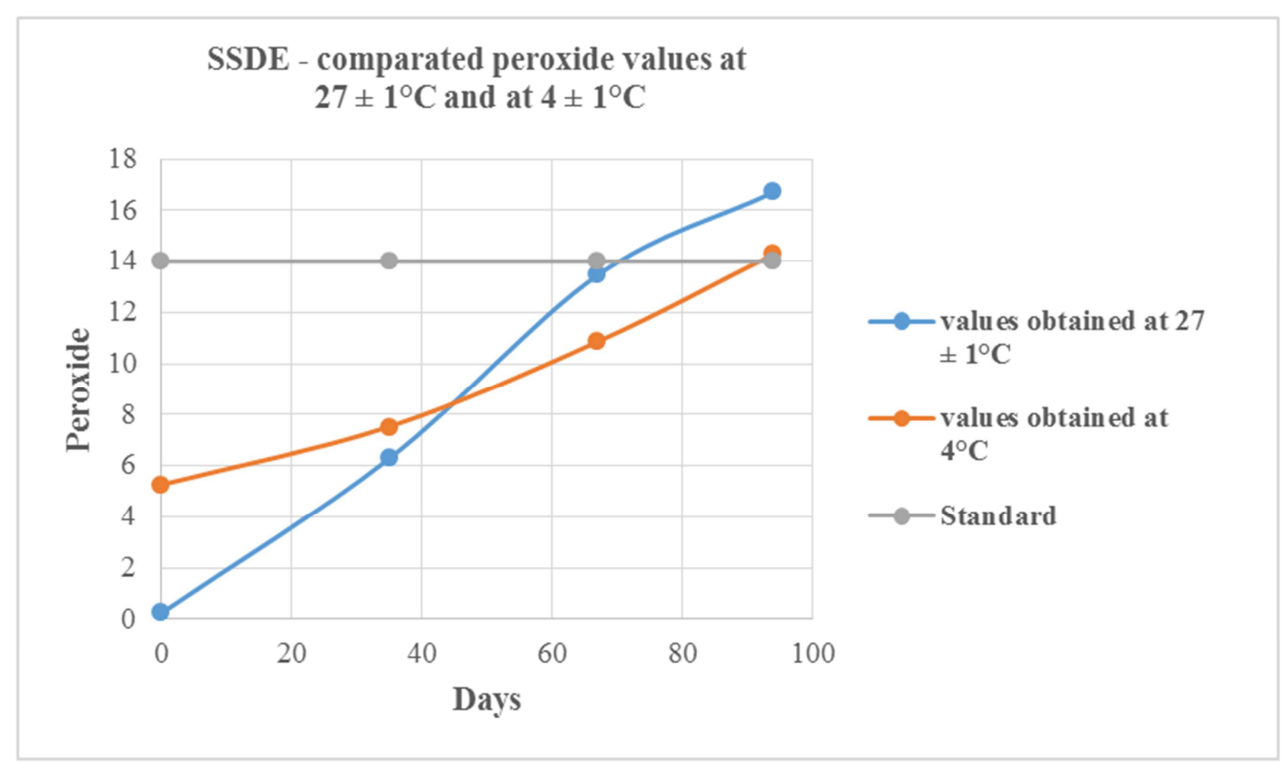

Figure 4. SSDE, evolution of the peroxide values at room temperature $27 \pm 1^{\circ} \mathrm{C}$ and at $4 \pm 1^{\circ} \mathrm{C}$.

The following information were observed: at $27 \pm 1^{\circ} \mathrm{C}$, the maximum standard acid value $(2.5 \mathrm{mg} \mathrm{KOH} / \mathrm{g}$ fat $)$ was reached after 43 days but at $4 \pm 1^{\circ} \mathrm{C}$, this value was reach after 54 days. The peroxide maximum recommended value (14.0 meq $\mathrm{O}_{2} / \mathrm{Kg}$ ) was achieved after 67 days and 95 days respectively at room and freezer temperature. From the analysis of these data, it appears that the peroxide value increases at the same time as the acidity, whatever the temperature at which the fat was maintained. This fat could be conserved at freezer temperature $\left(4 \pm 1^{\circ} \mathrm{C}\right)$ during 54 days with preservation of quality properties and at room temperature during 43 days (Table 5). Literature report that SSDE refined fat could be conserved for 56 days at $10^{\circ} \mathrm{C}$ [11].

\section{Conclusion}

The report of our work is the first on the purification of fats from BTL and SSDE using local reagents in Benin. The physicochemical properties of studied fats satisfy in majority the international standards (Codex Alimentarius). The two fats were rich in oleic, stearic and palmitic acids with respectively $25.94 \% ; 34.99 \% ; 24.50 \%$ for BTL fat and $34.37 \% ; 21.36 \% ; 24.59 \%$ for SSDE fat. Their $\omega 3$ contents (1.25\% and $1.56 \%$ respectively for BTL fat and SSDE fat) were interesting. The BTL fat could be stored for 94 days at $4 \pm 1^{\circ} \mathrm{C}$ and for 59 days at $27 \pm 1^{\circ} \mathrm{C}$ but SSDE fat for 54 days at $4 \pm 1{ }^{\circ} \mathrm{C}$ and 43 days at $27 \pm 1^{\circ} \mathrm{C}$, with preservation of their quality properties. These refined fats could be used in several sectors such as: energy, oleochemistry, cosmetology, animal feed, agri-food, etc.

\section{Acknowledgements}

The authors would like to thank Eric Mignolet and all the staff of faculty of Bioscience Engineering \& Institute of Life Sciences of Université Catholique de Louvain, for the GC analysis.

\section{Conflict of Interest}

The authors declare no conflict of interest.

\section{References}

[1] Association nationale des organisations professionnelles d'éleveurs de ruminants (ANOPER) (2014) Pour l'essor d'un élevage familial des ruminants qui nourrit le Bénin et sécurise l'avenir des éleveurs, 30 points de repère. Document d'orientation stratégique: 1-56. Bénin

[2] d'Orgeval R, Nonfon WR, Dèka E (1989) Evaluation des performances du porc local au Bénin. Séminaire sur la production porcine en Afrique tropicale: 1-10 Yaoundé, Cameroun

[3] Montcho M (2014) Entreprenariat agricole: la porciculture, un métier qui nourrit bien son homme.

https://agricultureaufeminin.wordpress.com. Accessed 04 March 2017

[4] Collège des enseignants de nutrition (2010-2011) Les catégories d'aliments. Université médicale virtuelle francophone: 1-31. Accessed 20 Apr. 2017

[5] Conseil Supérieur de la Santé (2011) Sécurité des huiles et graisses. 8310: 1 - 63 www.css-hgr.be. Accessed 15 Feb. 2017

[6] Iverson JL, Eisner J, Firestone D (1965) Detection of trace fatty acids in fats and oils by urea fractionation and gas-liquid chromatography. J Am Oil Chem Soc 42: 1063-1068

[7] Sreenivasan B (1968) Component fatty acids and composition of some oils and fats. J Am Oil Chem Soc 45: 259-265

[8] Girard P (2008) Valorisation de graisses animales en alimentation porcine. TechniPorc 31 (4): 1-25

[9] Kpoviessi DSS, Accrombessi GC, Kossouoh C, Soumanou MM, Moudachirou M (2004) Propriétés physico-chimiques et composition de l'huile non conventionnelle de pourghère (Jatropha curcas) de différentes régions du Bénin. C R Chimie 7: $1007-1012$ 
[10] ALINORM 99/17 (1999) Rapport de la seizième session du comité du codex sur les graisses et les huiles. Commission du codex alimentarius, London

[11] Büchler E (2013) Huiles et graisses. Pistor: 1-68. www.pistor.ch/graisses. Accessed 08 Jun 2016

[12] FAO (2014) Graisses et acides gras dans la nutrition humaine. Rapport d'une consultation d'experts,: 1 - 194. Rome

[13] Sonntag NOV (1979) Structure and composition of fats and oils. Bailey's industrial oil and fat products, WileyInterscience: 4, (1), 1-98. New-York

[14] Schaefer EJ (2002) Lipoproteins, nutrition, and heart disease. Am J Clin. Nutr 75: 191- 212

[15] Greenfield et Southgate (2007) Liste des ouvrages essentiels sur les banques de données sur la composition des aliments. Annexe 7: 244-246. Belgique
[16] CODEX STAN 211 (1999) Norme pour les graisses animales portant un nom spécifique.

ftp://ftp.fao.org/codex/standard/fr/CXS_211f.pdf. Accessed 25 Jan. 2016

[17] Nutrition Infos (2013) Toxines intimes. www.nutritionniste.be. Accessed 24 Nov. 2016

[18] MRAD N, ALOUI F, TAZEROUT M, NASRALLAH SB (2009) École des Mines de Nantes, Département Systèmes Energétiques et Environnement (DSEE), GEPEA, CNRSUMR 6144, 4 rue Alfred Kastler, BP20722 - 44307 Nantes Cedex 03 - France

[19] Commission Regulation (EC) No 608/2004 (2004) Regulation concerning the labeling of foods and food ingredients with added phytosterol, phytosterol esters, phytostanols and/or phytostanol esters (Text with EEA relevance) https://publications.europa.eu/en/publication-detail. Accessed 15 March 2016 